\title{
The Performance Analysis of Beibu Gulf airlines Based on DEA Model during the Pre-COVID-19 Pandemic Period
}

\author{
Yichia Lin ${ }^{1}$, Wenlung Chang ${ }^{2 *}$, Wongchai Anupong ${ }^{3 *}$, Bowen Long ${ }^{1}$ \\ ${ }^{1}$ School of Tourism and Culture, Nanning Normal University, Nanning, China \\ ${ }^{2}$ School of Education Science, Nanning Normal University, Nanning, China \\ ${ }^{3}$ Department of Agricultural Economy and Development, Chiang Mai University, Chiang Mai, Thailand \\ *Corresponding Authors.
}

\begin{abstract}
During the COVID-19 pandemic period, all airlines experienced a severe impact and the route operating cost is very susceptible to the impact of flight duration and aviation fuel prices. This paper analyzes the operation performance of Beibu Gulf airlines (low cost airline company) with data envelopment analysis CCR model in preCOVID-19 pandemic period. Under the domestic vigorous promotion of tourism development and people's huge demand for travel, the airlines in mainland China continue rapid development, which accelerates the emergence of local airlines other than the four major airlines and leads to increasingly fierce operation competition in the civil aviation industry. Behind the competition among airlines, the operational performance of airlines can best reflect the company's development status. In this context, airlines should choose appropriate operational strategies to strengthen its competitiveness and operational capabilities. The DEA model is a mature input-output research tool, and there have been many studies related to operational performance of the aviation industry. By using Data Envelopment Analysis (DEA) solver software, the input and output indicators from 2017 to 2019 are analyzed. Preliminary results show that routes and oil price factors have not reached effective status. Beibu Gulf Airlines gradually shifts to low-cost mode, the faced challenges are as follows: 1. The competition among domestic lowcost airlines; 2 . The current poor overall service quality of low-cost airlines as evaluated by customers; 3 . How to arrange routes, flight, service strategy, etc. Airbus uses enhanced aviation systems for this series of aircraft to improve the overall reliability of the aircraft, reduce maintenance and spare parts costs, thus helping airlines greatly reduce maintenance costs, which is very beneficial to low-cost airlines. Based on this, this paper puts forward some suggestions, such as optimizing routes, developing feeder flights in second tier cities of popular destinations, controlling fuel costs, making low-cost aviation fuel reserves, reducing the weight of passengers' carry-on luggage or charging additional baggage charges.
\end{abstract}

Keywords COVID-19 pandemic period, Data Envelopment Analysis (DEA) model, performance

\section{Introduction}

During the COVID-19 pandemic period, all airlines experienced a severe impact. Under the domestic vigorous promotion of tourism development and people's huge demand for travel, the airlines in mainland China continue rapid development, which accelerates the emergence of local airlines other than the four major airlines and leads to increasingly fierce operation competition in the civil aviation industry. Behind the competition among airlines, the operational performance of airlines can best reflect the company's development status. In this context, airlines should choose appropriate operational strategies to strengthen its competitiveness and operational capabilities. The DEA model is a mature input-output research tool, and there have been many studies related to operational performance $[1,2,3]$ of the aviation industry. For a long time, low-cost airlines sell air tickets at very low prices, mainly depending on high attendance and high aircraft turnover to achieve profitability. Affected by the epidemic, people across the world try to reduce their trips, and air tickets and travel orders have encountered "a wave of

ISSN: 0010-8189

(C) CONVERTER 2021

www.converter-magazine.info 
unsubscription". In addition, airlines in multiple countries limit the number of passengers on each flight and take measures such as ticket sales for every other seat to reduce the infection risk. Due to these factors, low-cost airlines can no longer achieve profitability with high attendance. Therefore, mastery of the operating model before the epidemic will help adjustment and operation after the epidemic.

To sum up, although domestic airlines are developing rapidly, there are still weaknesses and deficiencies in various aspects. It is necessary to improve the overall corporate strength by improving operational performance. This paper examines the input and output from a management perspective, using DEA model and its model as well as DEAsolver software for calculation. In recent years, Data Envelopment Analysis (DEA) is widely used to evaluate the benefits of several applications in different types of entities, as well as different activities in countries with different backgrounds. One reason is that there are often unknown complex factors, many activities involve multiple input and output relationships, while DEA provides the possibility of solving these situations. Such examples include: maintenance activities at U.S. Air Force bases in different geographical locations, the distribution of police forces in the United Kingdom and Wales, the effectiveness of branches in Cyprus and Canada, and the effectiveness of universities in the United States, the United Kingdom, and France in education and research. With a variety of inputs and outputs (including "society" and "safety net" expenditure as input data, and "quality of life" in various aspects as output data), these types of applications are extended to evaluate the implementation efficiency of cities, regions and countries. DEA model is used to study and analyze Beibu Gulf Airlines' operational performance. Some suggestions are raised for problems in the allocation of school resources in the operation performance to help improve the operation strategy.

\section{Methodology}

Data envelopment analysis (DEA) and its model [4]. In DEA, the evaluated unit or organization acts as a decision making unit (abbreviated as Decision Making Units (DMU). DEA establishes a data envelope curve by selecting the most relevant input and output data for DMU based on linear programming with optimal input and output as the cutting-edge data for production. Where, the effective point is located on the front surface, with the efficiency value calibrated to 1; the invalid point is located outside the front surface, which is assigned with a relative efficiency value index greater than 0 but less than 1 .

The information that DEA can provide includes the efficiency of decision-making units and method regarding how to improve invalid decision-making units into effective decision-making units. This is an effective way to help managers improve organizational efficiency. The entire DEA research has been systematically discussed [5].

The CCR model was proposed by Charnes, Cooper and Rhodes in 1978 to calculate the resource allocation efficiency under constant returns to scale. The basic concept of the CCR model is to perform linear combination using the output and input factors of the selected decision-making unit under constant rewards, and then use the ratio of the two-linear combination to represent the relative efficiency of the decision-making unit. It is assumed that there are $\mathrm{n}$ decision-making units [6].

$$
\begin{aligned}
& \operatorname{Max} \mathrm{h}_{\mathrm{i}}=\frac{\sum_{\mathrm{r}-1}^{\mathrm{s}} \mathrm{u}_{\mathrm{r}} Y_{\mathrm{rj}}}{\sum_{\mathrm{i}=1}^{\mathrm{m}} \mathrm{v}_{\mathrm{i}} X_{\mathrm{ij}}} \\
& \text { s.t. } \frac{\sum_{\gamma=1}^{s} \mathrm{u}_{r} Y_{\mathrm{rj}}}{\sum_{\mathrm{i}=2}^{\mathrm{m}} \mathrm{v}_{\mathrm{i}} \mathrm{X}_{\mathrm{ij}}} \leq 1, \mathrm{j}=1,2, \cdots \bullet, \mathrm{n} \\
& \mathrm{u}_{\mathrm{r}} \geq 0, \mathrm{v}_{\mathrm{i}} \geq 0 \\
& \mathrm{r}=1,2, \bullet \bullet \bullet, s \\
& \mathrm{i}=1,2, \bullet \bullet, \mathrm{m}
\end{aligned}
$$

Yrj represents the r-th output quantity of the j-th DUM; Xij represents the i-th input quantity of the j-th DUM. Ur

ISSN: 0010-8189

C CONVERTER 2021

www.converter-magazine.info 
and $\mathrm{Vi}$ are the weight coefficients of the r-th type input and the i-th type output, respectively.

Regarding the selection of input and output indicators, first, the selected indicators must truly reflect the airline's operational performance, and secondly, avoid significant linear relationship between input and output. According to the collected data, evaluation purpose and selection requirements, the selected input indicators are: number of aircraft, number of seats, number of routes, fuel prices, flight attendants; output indicators are: annual operating income, net profit.

Table 1 2017-2019 Data table

\begin{tabular}{|l|l|l|l|l|l|l|l|}
\hline Year & $\begin{array}{l}\text { Number } \\
\text { of } \\
\text { aircraft }\end{array}$ & $\begin{array}{l}\text { Number } \\
\text { of seats }\end{array}$ & $\begin{array}{l}\text { Number } \\
\text { of } \\
\text { routes } \\
\text { price(yuan/ton) }\end{array}$ & $\begin{array}{l}\text { Fuel } \\
\text { attendant }\end{array}$ & $\begin{array}{l}\text { Annual } \\
\text { operating } \\
\text { income } \\
(10,000 \\
\text { yuan })\end{array}$ & $\begin{array}{l}\text { Net } \\
\text { profit } \\
(10,000 \\
\text { yuan })\end{array}$ \\
\hline 2017 & 23 & 2882 & 52 & 3492.41 & 98 & 204700 & 4700 \\
\hline 2018 & 25 & 3242 & 58 & 4493.25 & 108 & 238400 & 700 \\
\hline 2019 & 27 & 3602 & 62 & 4229.5 & 118 & 279100 & 5400 \\
\hline
\end{tabular}

\section{Results}

According to the collected data, DEA-solver software is used for calculation to obtain: input and output data statistics table, data correlation table.

Table 2. Input and output data statistics table

\begin{tabular}{|l|l|l|l|l|l|l|l|}
\hline \multicolumn{2}{|l|}{ Statisitcs on Input/Output Data } \\
\hline
\end{tabular}


Volume 2021, No. 5

\begin{tabular}{|l|l|l|l|l|l|l|l|}
\hline SD & 1.6329931 & $\begin{array}{l}293.93876 \\
62\end{array}$ & $\begin{array}{l}4.1096093 \\
3531262\end{array}$ & $\begin{array}{l}423.5493 \\
46\end{array}$ & $\begin{array}{l}8.1649658 \\
09\end{array}$ & 30418.452 & $\begin{array}{l}2070.4266 \\
87\end{array}$ \\
\hline
\end{tabular}

When the Correlation between two data is 1 , it is a positive correlation, and when it is smaller than 1 , it means need for improvement. According to the calculation results in Table 2, only the correlation between the number of aircraft, the number of seats and the flight attendants is 1, indicating that the strategy of purchasing A320 and E190 to expand the fleet and recruiting flight attendants is effective and can be retained as a strategy. According to the ratio of crew members, it is possible to reduce the number of flight attendants in view of the number of passengers on the plane under the premise of ensuring safety, as saving personnel costs is also one of the keys. The correlation between the number of routes and the number of aircrafts, flight attendants, and seats does not reach 1 , which means that the layout of the routes needs adjustment. Routes can be adjusted appropriately according to seasons, holidays, route market environmental factors, etc., and route costs and benefits can be scientifically matched to reasonably evaluate the route benefits. Scientific planning of routes can fully increase the aircraft utilization rate and reduce operational costs. Observing whether the passenger load factor of the optimized route meets the standard level is also a key to route evaluation. The correlation between annual operating income and the number of aircraft, flight attendants, and seats reaches 0.9 , but the related strategies can be retained, since there is a positive correlation between the latter three, which means small or even no impact on annual operating income. In contrast, the most influential factor should be fuel price. The correlation between fuel price and various data is very low, and one possible reason is global fuel price fluctuation. Jet fuel costs have become one main cost of many airlines. Jet fuel costs account for up to $22 \%$ of total costs and $30 \%$ of main business costs. The increase in jet fuel prices greatly affects profits. For its reason, it is possible that fleet expansion of domestic airlines results in tight domestic airspace resources. This directly leads to an increase in aircraft take-off and landing ground sliding time and air flight time, thereby increasing fuel consumption. Airlines should strengthen ability to save fuel and control fuel to improve fuel efficiency.

Table 3 Data correlation table

\begin{tabular}{|c|c|c|c|c|c|c|c|}
\hline \multicolumn{8}{|l|}{ Correlation } \\
\hline & $\begin{array}{l}\text { Numbe } \\
\text { r of } \\
\text { aircraft }\end{array}$ & $\begin{array}{l}\text { Number of } \\
\text { seats }\end{array}$ & $\begin{array}{l}\text { Number of } \\
\text { routes }\end{array}$ & $\begin{array}{l}\text { Fuel } \\
\text { price(yua } \\
\text { n/ } \\
\text { ton) }\end{array}$ & $\begin{array}{l}\text { Flight } \\
\text { attendant }\end{array}$ & $\begin{array}{l}\text { Annual } \\
\text { operating } \\
\text { income } \\
(10,000 \\
\text { yuan })\end{array}$ & $\begin{array}{l}\text { Net profit } \\
(10,000 \\
\text { yuan })\end{array}$ \\
\hline $\begin{array}{l}\text { Number } \\
\text { of aircraft }\end{array}$ & 1 & 1 & $\begin{array}{l}0.9933992 \\
67798783\end{array}$ & $\begin{array}{l}0.710462 \\
04\end{array}$ & 1 & $\begin{array}{l}0.9985278 \\
94\end{array}$ & $\begin{array}{l}0.1380265 \\
26\end{array}$ \\
\hline $\begin{array}{l}\text { Number } \\
\text { of seats }\end{array}$ & 1 & 1 & $\begin{array}{l}0.9933992 \\
67798783\end{array}$ & $\begin{array}{l}0.710462 \\
04\end{array}$ & 1 & $\begin{array}{l}0.9985278 \\
94\end{array}$ & $\begin{array}{l}0.1380265 \\
26\end{array}$ \\
\hline $\begin{array}{l}\text { Number } \\
\text { of routes }\end{array}$ & $\begin{array}{l}0.9933 \\
99267 \\
79878 \\
3\end{array}$ & $\begin{array}{l}0.9933992 \\
67798783\end{array}$ & 1 & $\begin{array}{l}0.786496 \\
4714312 \\
14\end{array}$ & $\begin{array}{l}0.9933992 \\
67798783\end{array}$ & $\begin{array}{l}0.9857150 \\
52275015\end{array}$ & $\begin{array}{l}0.0235055 \\
05721303\end{array}$ \\
\hline
\end{tabular}


Volume 2021, No. 5

\begin{tabular}{|c|c|c|c|c|c|c|c|}
\hline $\begin{array}{l}\text { Fuel } \\
\text { price(yua } \\
\text { n/ } \\
\text { ton) }\end{array}$ & $\begin{array}{l}0.7104 \\
6204\end{array}$ & $\begin{array}{l}0.7104620 \\
4\end{array}$ & $\begin{array}{l}0.7864964 \\
71431214\end{array}$ & 1 & $\begin{array}{l}0.7104620 \\
4\end{array}$ & $\begin{array}{l}0.6712451 \\
1\end{array}$ & $\begin{array}{l}- \\
0.5989371 \\
36\end{array}$ \\
\hline $\begin{array}{l}\text { Flight } \\
\text { attendant }\end{array}$ & 1 & 1 & $\begin{array}{l}0.9933992 \\
67798783\end{array}$ & $\begin{array}{l}0.710462 \\
04\end{array}$ & 1 & $\begin{array}{l}0.9985278 \\
94\end{array}$ & $\begin{array}{l}0.1380265 \\
26\end{array}$ \\
\hline $\begin{array}{l}\text { Annual } \\
\text { operating } \\
\text { income } \\
(10,000 \\
\text { yuan })\end{array}$ & $\begin{array}{l}0.9985 \\
27894\end{array}$ & $\begin{array}{l}0.9985278 \\
94\end{array}$ & $\begin{array}{l}0.9857150 \\
52275015\end{array}$ & $\begin{array}{l}0.671234 \\
511\end{array}$ & $\begin{array}{l}0.9985278 \\
94\end{array}$ & 1 & $\begin{array}{l}0.1915447 \\
98\end{array}$ \\
\hline $\begin{array}{l}\text { Net profit } \\
(10,000 \\
\text { yuan ) }\end{array}$ & $\begin{array}{l}0.1380 \\
26526\end{array}$ & $\begin{array}{l}0.1380265 \\
26\end{array}$ & $\begin{array}{l}0.0235055 \\
05721303\end{array}$ & $\begin{array}{l}- \\
0.598937 \\
136\end{array}$ & $\begin{array}{l}0.1380265 \\
26\end{array}$ & $\begin{array}{l}0.1915447 \\
98\end{array}$ & 1 \\
\hline
\end{tabular}

\section{Conclusion}

During the COVID-19 pandemic period, all airlines experienced a severe impact and the route operating cost is very susceptible to the impact of flight duration and aviation fuel prices [6,7,8]. According to the collected data, the average annual fuel price in 2018 increased by RMB 1,000 per ton compared to 2017. There are various factors influencing the increase in crude oil prices, but the main reason is the insufficient supply of crude oil. Other reasons include: crude oil production reduction agreement, domestic problems in oil-producing countries, oil pipeline damage, etc. Plus domestic huge demand, there will be huge impact on airlines, greatly increasing the cost of aircraft fuel, and also increasing fuel surcharges. This may make customers choose other modes of transportation or other flights with similar prices but superior overall services. HNA Group Co., Ltd., formerly known as Hainan Airlines Holding Co., Ltd. established on April 16, 1998, has its headquarter located in Haikou City, Hainan Province, which is a large-scale enterprise group with official background in China. The business involves air transportation as the main body, integrating airport service industry, hotel and tourism industry, commercial retail industry, logistics industry, financial service industry and other related industries. As stated in the 2018 annual report, HNA[9] focuses on full service as the primary strategy to gradually transform the six airlines of Tianjin Airlines, Lucky Air, Chang'an Airlines, Fuzhou Airlines, Urumqi Airlines, and Beibu Gulf Airlines into low-cost operation airlines. Beibu Gulf Airlines has gradually transformed into an airline with lowcost operation. After Beibu Gulf Airlines gradually shifts to low-cost mode, the faced challenges are as follows: 1 . The competition among domestic low-cost airlines; 2 . The current poor overall service quality of low-cost airlines as evaluated by customers; 3 . How to arrange routes, flight, service strategy, etc.

The strategy that needs to be clarified and adhered to is: E190 (EMBRAER manufactures E190 brand new aircraft), as the main regional flight aircraft [10,11], has the characteristics of high efficiency and low cost. Under the same conditions, by using the E190 passenger aircraft to perform flight tasks, airlines can save at least about $30 \%$ cost. A320 has a strong passenger capacity and better comfort [12], which can meet the passenger flight demand between large cities. Moreover, Airbus uses enhanced aviation systems for this series of aircraft to improve the overall reliability of the aircraft, reduce maintenance and spare parts costs, thus helping airlines greatly reduce maintenance costs, which is very beneficial to low-cost airlines.

ISSN: 0010-8189 


\section{References}

[1] Y. Xu, Y.S. Park, J.D. Park, \& Cho, W. "Evaluating the environmental efficiency of the US airline industry using a directional distance function DEA approach,” Journal of Management Analytics, vol. 8, no. 1, pp. 1-18, 2021.

[2] E.T. Losa, A. Arjomand, K.H. Dakpo, J. Bloomfield. (2020). "Efficiency comparison of airline groups in Annex 1 and non-Annex 1 countries: A dynamic network DEA approach,” Transport Policy, vol. 99, pp. 163-174, 2020.

[3] Z. Chen, P. Wanke, J.J.M Antunes, N. Zhang. "Chinese airline efficiency under CO2 emissions and flight delays: A stochastic network DEA model,” Energy Economics, vol. 68, pp. 89-108, 2017.

[4] A. Charnes, W. Cooper, A.Y. Lewin, L.M. Seiford. "Data envelopment analysis theory, methodology and applications," Journal of the Operational Research society, vol. 48, no. 3, pp. 332-333, 1997.

[5] A. Emrouznejad, G.L. Yang. "A survey and analysis of the first 40 years of scholarly literature in DEA: 1978-2016,” Socio-economic planning sciences, vol. 61, pp. 4-8, 2018.

[6] R. Sickles, V. Zelenyuk. Measurement of Productivity and Efficiency: Theory and Practice. Cambridge: Cambridge University Press. 2019.

[7] H. Wang, X. Gao. "Oil price dynamics and airline earnings predictability," Journal of Air Transport Management, vol. 87, pp. 101854, 2020.

[8] C. Kathiravan, M. Selvam, B. Maniam, S. Venkateswar. "Relationship between crude oil price changes and airlines stock price: The case of Indian aviation industry," International Journal of Energy Economics and Policy, vol. 9, no. 5, pp. 7, 2019.

[9] R.N. Killins (2020). The impact of oil on equity returns of Canadian and US Railways and airlines. The North American Journal of Economics and Finance, vol. 52, pp. 101178, 2020.

[10] J. Chen, Y. Wang. "The pricing effects of entry by Hainan airlines: Evidence from the US-China international air travel market," Journal of Economics and Business, vol. 114, pp. 105957, 2021.

[11] R.P. De Oliveira, A.V. Oliveira, G. Lohmann. “A Network-Design Analysis of Airline Business Model Adaptation in the Face of Competition and Consolidation," Transportation Science, vol. 55, no. 2, pp. 532-548, 2021.

[12] R.R. Narcizo, A.V. Oliveira, M.E. Dresner. "An empirical model of airline fleet standardization in Brazil: Assessing the dynamic impacts of mergers with an events study," Transport Policy, vol. 97, pp. 149-160, 2020.

[13] H. Han, B. Koo, S.S. Hyun. "Image congruity as a tool for traveler retention: A comparative analysis on South Korean full-service and low-cost airlines," Journal of Travel \& Tourism Marketing, vol. 37, no. 3, pp. 347-360, 2020. 